\title{
Involvement of Protein Kinase A in Patterning of the Mouse Somatosensory Cortex
}

\author{
Ruth F. Watson, ${ }^{1}$ Raja M. Abdel-Majid, ${ }^{2}$ Mark W. Barnett, ${ }^{1}$ Brandon S. Willis, ${ }^{3}$ Alla Katsnelson, ${ }^{1}$ \\ Thomas H. Gillingwater, ${ }^{1}$ G. Stanley McKnight, ${ }^{3}$ Peter C. Kind, ${ }^{1 \star}$ and Paul E. Neumann ${ }^{2 \star}$ \\ ${ }^{1}$ Centre for Integrative Physiology, Centre for Neuroscience, University of Edinburgh, Edinburgh EH8 9XD, United Kingdom, ${ }^{2}$ Department of Anatomy and \\ Neurobiology, Dalhousie University, Halifax, Nova Scotia, Canada B3H 1X5, and ${ }^{3}$ Department of Pharmacology, University of Washington, Seattle, \\ Washington 98195
}

Patterning of the mouse somatosensory cortex is unusually evident because of the presence of a "barrel field." Presynaptic serotonin and postsynaptic glutamate receptors regulate barrel formation, but little is known of the intracellular signaling pathways through which they act. To determine whether protein kinase A (PKA) plays a role in the development of the barrel field, we examined five viable PKA subunit-specific knock-out (KO) mouse lines for barrel field abnormalities. Barrels are present in these mice, but those lacking the RII $\beta$ subunit display significantly reduced contrast between the cell densities of barrel hollows and sides compared with wild-type animals. Thalamocortical afferent segregation in the posterior medial barrel subfield appeared normal, suggesting a postsynaptic site of gene action for the RII $\beta$ protein. Immunoelectron microscopy confirmed that RII $\beta$ was selectively localized to dendrites and dendritic spines. Mice lacking RII $\beta$ show reduced glutamate receptor A (GluRA) subunit insertion into the postsynaptic density in postnatal day 7 somatosensory cortex; however, GluRA KO mice developed normal barrels. Our results clearly demonstrate a role for postsynaptic PKA signaling pathways in barrel differentiation. They also demonstrate a clear dissociation between the regulation of GluRA trafficking by PKA and its role in barrel formation. Finally, although a role for PKA downstream of cAMP cannot be ruled out, these data suggest that PKA may not be the principle downstream target because none of the mutants showed a barrelless phenotype similar to that observed in adenylate cyclase type $1 \mathrm{KO}$ mice. These results give insight into activity-dependent mechanisms that regulate barrel formation.

Key words: barrel; cAMP; protein kinase A; somatosensory cortex; development; NMDA receptor

\section{Introduction}

A fundamental concept of the structure and function of the cerebral cortex is arrangement of sensory and motor systems into distinct topographically defined domains. In the primary somatosensory cortex (SI) of rodents, periphery-related patterns of sensory receptors are recapitulated in layer IV as an array of multineuronal structures ("barrels") called the barrel field (Woolsey and Van der Loos, 1970). In barrels, neurons are arranged in cylindrical or oval-shaped rings that are separated from their neighbors by hypocellular "septa." In mice, cell-dense barrel walls surround a cell-sparse "hollow" that contains thalamocortical afferent (TCA) terminals (Woolsey and Van der Loos, 1970).

Postsynaptic glutamate signaling regulates barrel formation (Erzurumlu and Kind, 2001; Kind and Neumann, 2001). Genetic ablation of either metabotropic glutamate receptor 5 (mGluR5) (Hannan et al., 2001) or cortical NR1 (Iwasato et al., 2000), the

Received 0ct. 12, 2005; revised March 23, 2006; accepted March 25, 2006.

This work was supported by the Medical Research Council of Great Britain (P.C.K.), the Wellcome Trust (P.C.K.), the Medical Research Council of Canada (Grant MA-14218 to P.E.N.), and the National Institutes of Health (G.S.M.). We thank Rolf Sprengel for supplying the GluRA KO mice.

*P.C.K. and P.E.N. contributed equally to this work.

Correspondence should be addressed to Peter C. Kind, Centre for Integrative Physiology, Centre for Neuroscience, University of Edinburgh, Hugh Robson Building, George Square, Edinburgh EH8 9XD, UK. E-mail: pkind@ed.ac.uk. DOI:10.1523/JNEUROSCI.0750-06.2006

Copyright $\odot 2006$ Society for Neuroscience $\quad$ 0270-6474/06/265393-09\$15.00/0 essential subunit of the NMDA receptor, results in a complete loss of cellular segregation in layer IV despite at least partial segregation of TCAs. Serotonin signaling also regulates barrel formation (Gaspar et al., 2003). Overexpression of 5-HT causes a near-complete loss of barrels that can be rescued by ablation of presynaptic 5- $\mathrm{HT}_{1 \mathrm{~B}}$ receptors (Salichon et al., 2001). Although much is known about the neurotransmitter receptors that regulate barrel formation, little is known of the intracellular signaling pathways through which they act.

Several findings suggest a role for cAMP-dependent protein kinase A (PKA) in barrel formation. PKA is present in both axon terminals and postsynaptic densities (PSDs) and can be regulated by $5-\mathrm{HT}_{1 \mathrm{~B}}$, NMDA, and mGlu 5 receptors. Furthermore, adenylate cyclase type 1 (Adcy1) mutant mice are "barrelless," showing no TCA segregation or cellular segregation in layer IV (Welker et al., 1996; Abdel-Majid et al., 1998). Loss of adenylate cyclase type 1 (AC1) may cause a barrelless phenotype by altering $5-\mathrm{HT}_{1 \mathrm{~B}}$ regulation of cAMP/PKA activity in TCAs, thereby reducing glutamate release (Abdel-Majid et al., 1998; Laurent et al., 2002). Direct evidence for a presynaptic site of action for AC1 comes from the finding that TCA segregation and cortical cell clustering is normal in mice with a cortex-specific deletion of AC1 (Iwasato et al., 2005).

A postsynaptic role for PKA in barrel formation has also been hypothesized (Kind and Neumann, 2001). PKA is involved in 
long-term potentiation (LTP) and long-term depression at developing TCA synapses (Lu et al., 2003), and it also plays a crucial role in developing visual cortex plasticity (Beaver et al., 2001; Fischer et al., 2004). PKA is a heterotetramer composed of two regulatory $(\mathrm{R})$ and two catalytic $(\mathrm{C})$ subunits. Four regulatory (Prkar1a, Prkar1b, Prkar2a, and Prkar2b) and two catalytic (Prkaca and Prkacb) subunit genes have been identified and disrupted by homologous recombination (Brandon et al., 1997). Loss of the RI $\alpha$ subunit in Prkarla knock-out (KO) mice is an embryonic lethal condition (Amieux et al., 2002). To determine whether PKA plays a role in barrel formation, we examined the barrelfield morphology in the five viable PKA null mutant mice.

\section{Materials and Methods}

Animals. Targeting of embryonic stem cells, establishment of chimeras, and mouse lines carrying mutations in the $\mathrm{C} \alpha, \mathrm{C} \beta, \mathrm{RI} \alpha, \mathrm{RI} \beta$, and RII $\beta$ PKA subunit genes have been described (Brandon et al., 1995, 1998; Qi et al., 1996, Skalhegg et al., 2002). For initial analysis of barrel phenotype, mice were maintained at University of Washington, Seattle. Ten-weekold mice, from different litters, homozygous for targeted disruptions of the PKA subunit genes RI $\beta(n=3), \operatorname{RII} \alpha(n=3), \operatorname{RII} \beta(n=8), \mathrm{C} \alpha(n=$ $3)$, and $C \beta(n=3)$ were given a lethal dose of sodium pentobarbitol and then were perfused transcardially with $0.1 \mathrm{~m}$ PBS, $\mathrm{pH} 7.4$, followed by $4 \%$ chilled paraformaldehyde in $0.1 \mathrm{M}$ PBS. Brains were postfixed for $24 \mathrm{~h}$ in the same fixative and transported to Dalhousie University for subsequent analysis. Brains were sectioned serially parallel to the pial surface overlying the SI at a thickness of $50 \mu \mathrm{m}$ using a vibratome. Sections were mounted on gelatin-coated slides, dried overnight, and then stained either with cresyl violet (Nissl) stain or cytochrome oxidase (CO) histochemistry. CO histochemistry was performed as described by WongRiley (1979). After completion of the staining reaction, sections were rinsed, dehydrated through series of alcohol, cleared in xylene, and coverslipped. For further analysis of RII $\beta$ KO mice, mice were maintained at the University of Edinburgh on a C57BL/6J background. GluRA KO mice (Zamanillo et al., 1999) were obtained from Dr. Rolf Sprengel (MaxPlanck-Institut für medizinische Forschung, Heidelberg, Germany).

Histology and immunohistochemistry. Animals ranging in age from postnatal day 4 (P4) to adult were killed and perfused as above, then brains were removed and postfixed for at least $6 \mathrm{~h}$ in $4 \%$ paraformaldehyde, and then equilibrated overnight in $30 \%$ sucrose. Brains were sectioned $(48 \mu \mathrm{m})$ on a freezing microtome either coronally to reveal cortical layers and thalamic nuclei or tangential to the pial surface to reveal a full barrel field. For tangential sections, cortices were dissected from the thalamus and the hippocampus and striatum removed. The cortex was then flattened on the freezing microtome stage with the pial surface facing up. Sections were either mounted on gelatin-coated slides and stained with cresyl violet or thionin to reveal cellular distribution or placed in primary antibodies, free floating overnight, to reveal the localization of PKA RII $\beta$, serotonin transporter (SERT), or GluRA. All immunohistochemistry was performed according to previously described protocols (Hannan et al., 2001; Vitalis et al., 2002) with the following exceptions. Two diluents were used for incubation of tissue in primary and secondary antibodies. Initially antibodies were diluted in PBS containing $0.2-0.5 \%$ Triton $\mathrm{X}-100$. This protocol was changed to dilution in DMEM containing $5 \%$ fetal calf serum and $0.2-0.5 \%$ Triton X-100 because it reduces nonspecific background staining (Kind et al., 1994). Sections for immunohistochemistry were incubated overnight in rabbit anti-mouse PKA RII $\beta$ (1:600-1:2000; Santa Cruz Biotechnology, Santa Cruz, CA), goat anti-rabbit GluRA (1:250; Upstate Biotechnology, Lake Placid, NY), or goat anti-rabbit SERT (1:2000; Calbiochem, La Jolla, CA), followed by biotinylated anti-rabbit antibodies. Visualization was performed using a Vectastain ABC kit (Vector Laboratories, Burlingame, $\mathrm{CA}$ ) with DAB as the chromogen. In all cases, sections were dehydrated into xylene and coverslipped. For cell counts, $48 \mu \mathrm{m}$ tangential sections were immunolabeled for SERT (as above), but visualized using an AlexaFluor 568-conjugated goat anti-rabbit secondary antibody (1:200; Invitrogen, San Diego, CA). To reveal nuclei, free-floating sections were then counterstained by incubating them for $30 \mathrm{~min}$ in a solution con- taining Topro (1:1000; Invitrogen). Sections were rinsed in PBS, mounted on gelatin-coated slides, and coverslipped in PBS-glycerol $(3: 1, w / v)$.

Area measurements. All area measurements were obtained from tangential sections stained with anti-SERT antibody as described above. Images were captured at magnifications of $31.25 \times$ ( $\mathrm{S} 1$ cortex area), $62.5 \times$ [posterior medial barrel subfield (PMBSF) area], and $125 \times(\mathrm{C} 1$ barrel area, cortical thickness and cortical layer thickness measurements) using a Leica (Nussloch, Germany) DMLB microscope, Leica 480 digital camera, and the Leica DMLB Image Manager version 4.0 program. Area measurements were then performed on the digitized images using Image Tool for Windows version 3.0 software (University of Texas Health Science Centre at San Antonio, San Antonio, TX). Each image measurement was calibrated using a $1 \mathrm{~mm}$ graticule (Graticules, Tonbridge, Kent, UK). Results are reported as mean \pm SEM.

Cell counts. Sections stained with anti-SERT antibody and Topro were used for counting cells. Three to four adjacent sections containing the barrel-field representation were analyzed for each animal. From these sections, the position of individual barrels were determined, and a series of confocal images (Leica) of B3 and its neighboring barrels were taken with $7 \mu \mathrm{m}$ intervals using the 10 and $20 \times$ objectives. Morphometric analysis was performed with the Leica software (TCNST). For each series of optical images, the section containing the clearer representation of the barrel of interest was used to start the analysis. On this selected section, three rectangles along the $\mathrm{B} 2-\mathrm{B} 4$ axis, one containing the $\mathrm{B} 2-\mathrm{B} 3$ wall, one the B3 hollow, and one the B3-B4 wall, were drawn to calculate the density of Topro-stained nuclei in each rectangle. Measurements were done on the selected section and on the two adjacent sections (upper and lower). From these data, the average density of Topro-stained nuclei in the walls and hollow of the chosen barrel was calculated. Results are reported as means of average densities \pm SEM.

Immunoelectron microscopy. Animals for electron microscopy were perfused as above, except that $0.1 \%$ glutaraldehyde was included in the fixative. Fifty-millimeter-thick vibratome sections were placed in 1:200 dilution of anti-RII $\beta$ antibody overnight at $4^{\circ} \mathrm{C}$ in the absence of detergent and reacted for DAB histochemistry as described above. They were then postfixed in $1 \%$ osmium tetroxide in $0.1 \mathrm{~m}$ phosphate buffer for 45 min. After dehydration through an ascending series of ethanol solutions and propylene oxide, all sections were embedded on glass slides in Durcupan resin. Regions of cortex $\left(\sim 1 \times 1 \mathrm{~mm}^{2}\right)$ to be used for assessment were then cut out using a scalpel and glued onto a resin block for sectioning. Ultrathin sections $(\sim 70 \mathrm{~nm})$ were cut and collected on Formvarcoated grids (Agar Scientific, Stansted, UK), stained with uranyl acetate and lead citrate in a LKB-Wallac (Gaithersburg, MD) Ultrostainer, and then assessed in a Philips CM12 transmission electron microscope. Negatives taken in the microscope were scanned onto a Macintosh G5 computer (Apple Computers, Cupertino, CA) using an Epson (Long Beach, CA) 4870 photo flat-bed scanner at 1200 dots per inch, before being prepared for presentation in Adobe Photoshop (Adobe Systems, San Jose, CA),

Protein kinase A activity. The area of the SI of 1-week-old wild-type (WT; $n=3)$ and RII $\beta$ knock-out $(n=4)$ mice was excised and immediately immersed in liquid nitrogen. Protein homogenates were prepared in cold homogenization buffer (20 mm Tris, pH 7.6, $250 \mathrm{~mm}$ sucrose, 1 mM EGTA, 5 mm EDTA, 10 mm dithiothreitol, 5 mm magnesium acetate, $1 \%$ Triton X-100, $1 \mu \mathrm{g} / \mathrm{ml}$ leupeptine, $3 \mu \mathrm{g} / \mathrm{ml}$ aprotinin, $5 \mathrm{~mm} 4-(2-$ aminomethyl)benzenesulfonylfluoride hydrochloride, $0.1 \mathrm{mg} / \mathrm{ml}$ soybean trypsin inhibitor) using a Polytron, followed by brief sonication and centrifugation at $10,000 \mathrm{rpm}$ at $4^{\circ} \mathrm{C}$. Protein concentration was estimated using the Bradford assay (Bio-Rad, Hercules, CA), and samples were diluted to $2-3 \mathrm{mg}$ of protein/ml. Total and basal cAMP-dependent protein kinase (PKA) activities were measured with Kemptide substrate as described previously (Clegg et al., 1987), in the presence and absence of 5 $\mu \mathrm{M}$ cAMP, respectively. Nonspecific kinase activity that remained in the presence of the PKA inhibitor PKI was subtracted from both basal and total PKA activity.

Synaptosome and PSD preparations. Synaptosome preparations were prepared according to the methods of Dunkley et al. (1986). We used a strong homogenization step leaving little if any membrane attached to 

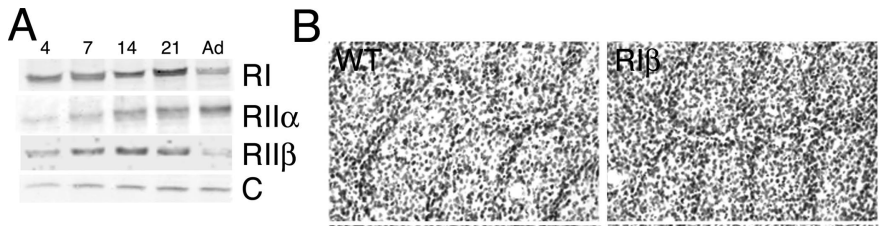

Figure 1. RII $\beta$ KO mice show reduced segregation of neurons in SI cortex. $\boldsymbol{A}$, Western blot analysis of synaptosome preparations revealed immunoreactive protein for $\mathrm{RI}, \mathrm{RII} \alpha, \mathrm{R} \| \beta$, and C subunits. Although antibodies specific for each of the $\mathrm{RI}$ and $\mathrm{C}$ subunits were not used, this result indicates that several different PKA holoenzymes are present at synapses throughout postnatal development of the barrel cortex. Whether these subunits are in the presynaptic terminal or part of the postsynaptic density could not be determined using this preparation. $\boldsymbol{B}$, Digitized images of cresyl violet (Nissl)-stained sections of layer IV of the SI of adult wild-type mice and RI $\beta, \mathrm{R} \mid \alpha$, RII $\beta, C \alpha$, and $(\beta$ null mutant (knock-out) mice. Barrels are present in PKA subunit-specific knock-out mice; however, mice lacking the RII $\beta$ subunit have poorly differentiated barrels. Scale bar, $200 \mu \mathrm{m}$.

the postsynaptic density; therefore, it contains a presynaptic terminal and postsynaptic proteins associated with the PSD. Briefly, SI cortex was homogenized in a $320 \mathrm{~mm}$ sucrose solution ( $\mathrm{pH} 7.4$, containing $1 \mathrm{~mm}$ EDTA and $5 \mathrm{~mm}$ Tris) and poured onto Percoll gradients ( $3 \mathrm{ml}$ layers of 24,10 , and $3 \%$ Percoll), which were centrifuged for $12 \mathrm{~min}$ at $15,000 \mathrm{rpm}$ at $4^{\circ} \mathrm{C}$. Synaptosomes were removed from between the 24 and $10 \%$ Percoll layers and spun for $30 \mathrm{~min}$ at 13,000 rpm in ice-cold $320 \mathrm{~mm}$ sucrose solution. The resulting synaptosome pellet was then resuspended and centrifuged in cold Krebs' buffer (containing $\mathrm{NaCl}, \mathrm{KCl}, \mathrm{MgSO}_{4}$, glucose, $\mathrm{Na}_{2} \mathrm{HPO}_{4} \cdot 12 \mathrm{H}_{2} \mathrm{O}$, and HEPES) without $\mathrm{Ca}^{2+}$ at $13,000 \mathrm{rpm}$ for 10 min, twice in succession. Synaptosomes were treated with lysis buffer [50 mm HEPES, pH 7.5, 1\% Triton X-100, $50 \mathrm{~mm} \mathrm{NaCl}$ containing protease inhibitors, phosphatase inhibitor mixtures I and II (P2850 and P5276; Sigma, St. Louis, MO)]. The PSD fraction was then pelleted by two successive centrifugations, in the presence or absence of $\mathrm{Ca}^{2+}(100 \mu \mathrm{m})$, at $36,800 \times g$ for $45 \mathrm{~min}$.

Western blotting. Mice were killed either by cervical dislocation or decapitation and SI cortices dissected from P4, P7, P14, P21, and adult mice were immediately frozen on dry ice and stored at $-70^{\circ} \mathrm{C}$. For developmental analysis, barrel cortices were homogenized in lysis buffer (50 mm HEPES, pH 7.5, 1\% Triton X-100, 50 mm NaCl containing protease inhibitors, phosphatase inhibitor mixtures I and II). Protein concentrations were determined by Bradford assays, and immunoblot analysis was performed according to the methods of Kind et al. (1994). Briefly, $10 \mu \mathrm{g}$ of protein were loaded per lane of each age on a 7 or $10 \%$ polyacrylamide gel with a $4 \%$ stacking gel. The proteins were then transferred to nitrocellulose membranes, which were then stained with amido black to confirm equal loading of protein. The blots were then incubated in primary antibody overnight [GluRA, 1:1000, Upstate Biotechnology; RII $\beta$, 1:600, Santa Cruz Biotechnology; PKA RI (RI), 1:500, BD Transduction Labs, San Diego, CA; PKAC (C), 1:1000, BD Transduction Labs; RII $\alpha, 1: 1000$, BD Transduction Labs; synapse-associated protein-102 (SAP-102), 1:5000, Chemicon; PSD-95, 1:20,000, Upstate Biotechnology] at room temperature before being placed in secondary antibodies (anti-mouse IgG, 1:10,000; anti-rabbit IgG, 1:25,000; anti-goat IgG, 1:50,000; Sigma), coupled to HRP for $1-2 \mathrm{~h}$. Proteins were visualized either using ECL reagents (Pierce, Rockford, IL) and XAR Kodak (Eastman Kodak, Rochester, NY) autoradiographic film or fluorescently coupled anti-rabbit (1:5000; Rockland, Gilbertsville, PA) or mouse (1:5000; Invitrogen) secondaries and visualized using the LiCor system. Densitometry was performed using either the Bio-Rad GS710 imager using the Bio-Rad Quantity One imaging software or the LiCor Odyssey imaging system and densitometry performed using NIH ImageJ software.

Analysis of gene expression using real-time reverse transcription-PCR. SI was dissected from P4, P7, P14, P21, and adult mice, frozen on dry ice, and stored at $-70^{\circ} \mathrm{C}$. Total RNA was extracted using an RNeasy mini-kit (Qiagen, Hilden, Germany) and an RNase-free DNase set (Qiagen). Total RNA was run on $0.8 \%$ agarose gel to ensure that RNA was not de-

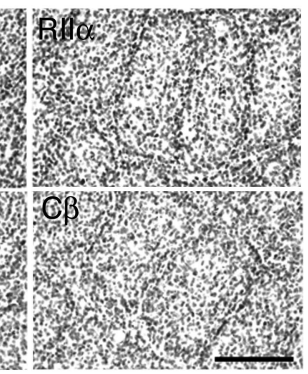

graded (28S ribosomal band was well defined and double the intensity of $18 \mathrm{~S}$ ribosomal band) or the sample was discarded. First-strand cDNA synthesis was performed as described by Barnett et al. (1998). Real-time reverse transcription-PCR (RT-PCR) was performed using MJ Research (Watertown, MA) DNA Engine Opticon and Quantitect SYBR green PCR kit (Qiagen). In each PCR reaction, $1 \mu$ l of cDNA was combined with gene-specific primers $(0.5 \mu \mathrm{M})$ and $12.5 \mu \mathrm{l}$ of QuantiTect SYBR green PCR master mix to a total volume of 25 $\mu$ l. To compare expression levels at different developmental stages, a dilution series of control cDNA was made and assayed in each Opticon run. The dilution series was used from cDNA of the developmental stage predicted to give the highest expression of the gene product being amplified. Other controls performed in each run were RT and water blanks.

At the end of each run, melting curve analysis was performed between 60 and $90^{\circ} \mathrm{C}$, single melting peak demonstrated specific product. OpticonMonitor analysis software (version 1.01) was used to compare amplification in experimental samples during the log-linear phase to the standard curve from the dilution series of control cDNA. Comparisons were displayed as histograms. 18S rRNA and glyceraldehyde-3-phosphate dehydrogenase were used as a loading control, and each bar was normalized to the level of $18 \mathrm{~S}$ rRNA expression. The following primer sets specific for each PKA subunit were checked using basic local alignment search tool: RII $\beta$-forward $(\mathrm{RII} \beta-\mathrm{F}), 5^{\prime}$-TAAACCGGTTCACAAGGCGTG-3'; RII $\beta$-reverse (RII $\beta$ R), $5^{\prime}$-GTTACCGACGCATCTTCCAAC-3'; RII $\alpha$-F, 5' -CGTCGTCGCCTTGGTCAATG-3'; RII $\alpha$-R, 5' -TGAGCAGAGATGCCGGCTTC-3'; RI $\alpha$-F, $5^{\prime}$-TGGAGAGCTGGCTTTGATTTA-3'; RI $\alpha$-R, 5' -GCTGTGCCCTCTAAAATGATG-3'; RI $\beta$-F, $5^{\prime}$-GGGGAAACAGTCATACAGCAA-3', RI $\beta$-R, 5'-CTCCAGGGATTCTAGGATGGA-3'; C $\alpha$-F, $5^{\prime}$ GAATACAGCCCAGTTGGATCA-3'; C $\alpha$-R, 5'-CTCGCCACCAGCTACATACTC-3'; C $\beta-\mathrm{F}, \quad 5^{\prime}$-GGGGAACACTGCGATCGCCAA- $3^{\prime}$; C $\beta$-R, $5^{\prime}$-CCAGGGACGTATTCCATAACC-3'; 18S-F, 5'-GTGGAGCGATTTGTCTGGTT-3'; 18S-R, 5' -CAAGCTTATGACCCGCACTT-3'.

\section{Results}

Morphology of cortical barrelfield in PKA mutant mice

To determine which PKA subunits are present at synapses in the developing barrel cortex, we performed Western blot analysis on synaptosome preparations (Fig. $1 A$ ) from developing barrel cortices. These synaptosome preparations use a strong initial homogenization so they consist of presynaptic terminals with attached PSDs. Little, if any, postsynaptic membrane remains attached to the PSD. All PKA subunits were present in synaptosomes through barrel cortex development. As expected, because of the rapid increase in synaptogenesis between P4 and P21 (White et al., 1997; Spires et al., 2005), total protein isolated from synaptosomes increased approximately fivefold during this time (data not shown), and expression of PKA subunits also increased during this time period. mRNA for all six of the PKA subunits were examined in developing SI cortex at all ages examined by real-time quantitative RT-PCR (supplemental Fig. 1, available at www.jneurosci.org as supplemental material). Similar to the Western blot analysis, mRNA for all PKA subunits were present throughout postnatal development, although there was often discordance between protein and mRNA levels. This appears to be a common feature of PSD-associated molecules and may be because of the rapid turnover of synapses and hence synaptic proteins during development (Barnett et al., 2006). Using ANOVA and linear regression analysis, only Prkar2b and Prkarca showed significant trends in variation of expression levels with age. 
Examination of the barrelfield using Nissl-stained sections revealed the presence of barrels in all five of the subunitspecific PKA knock-out mouse lines; however, one mutant line displayed defects in barrel morphology (Fig. $1 B$ ). In adult (10week-old) $\mathrm{RII} \beta \mathrm{KO}$ mice, barrels were hard to discern because the cell density appeared more uniform across septa and barrel hollows relative to the barrel sides than in WT animals or mice heterozygous for the RII $\beta$ null mutation. All other subunit specific mutants revealed normal cellular segregation with clear barrel walls, hollow, and septas in PMBSF. All five subunit-specific PKA knock-out mouse lines displayed normal barrel-like patches in cytochrome oxidase-stained sections of the SI (data not shown).

To elucidate the cellular mechanisms by which RII $\beta$ may be regulating barrel formation, we examined the expression pattern of the RII $\beta$ protein through development. RII $\beta$ is most strongly expressed in layer IV of the cortex of WT mice at P4 and $\mathrm{P} 7$ (Fig. 2A, $B$, respectively), where staining appears as diffuse neuropilar patches. That these patches correspond to the barrels was confirmed in tangential sections through layer IV at P7 where RII $\beta$ is at highest levels in SI (Fig. 2C). No immunoreactive product was seen in brains from RII $\beta$ KO mice, confirming the specificity of the antibody for the RII $\beta$ protein (supplemental Fig. 2, available at www. jneurosci.org as supplemental material).

We then examined the precise nature of the defects present in the RII $\beta$ null mutant mice at younger ages. Nissl-stained sections of 7-d-old WT and RII $\beta$ KO mice revealed decreased cellular segregation similar to that found in adults (Fig. 2D-G). In PMBSF, barrel walls and hollows can be seen, but cellular segregation is reduced. No barrels are visible in the anterior snout (AS) region. The cell densities in barrel walls and hollows were calculated to permit quantitative analysis of the segregation of cells in the barrelfields of WT and RII $\beta$ KO mice. Tangential sections were doublelabeled by Topro staining (for nuclei) and SERT immunohistochemistry (for TCAs to identify barrel hollows) (supplemental Fig. 3A, available at www.jneurosci.org as supplemental material). Nuclei were counted in images of $7 \mu \mathrm{m}$ optical sections obtained using the confocal microscope (supplemental Fig. 3B, available at www.jneurosci.org as supplemental material). The ratio of cell density in the barrel wall to that in the hollow was significantly less in RII $\beta$ KO mice than in WT mice (supplemental Fig. 4, available at www.jneurosci.org as supplemental material), confirming our qualitative assessment. No differences in overall density of cells in layer IV were seen, indicating that cell death was unaltered in the $\operatorname{RII} \beta$ mutants.

\section{Role of RII $\beta$ in TCA segregation}

To determine whether RII $\beta$ plays a role in TCA segregation, we next examined $\mathrm{CO}$ and SERT staining in RII $\beta \mathrm{KO}$ mice. The normal pattern in WT and RII $\beta$ KO mice contrasts markedly with the diffuse staining of the layer IV in barrelless (Adcy $1^{b r l}$ ) mutant mice (Welker et al., 1996) (data not shown). The implication that segregation of TCAs in PMBSF is normal in RII $\beta$ KO mice was confirmed with SERT immunohistochemistry (Fig. $3 A, B)$. No difference in patch size and distribution of TCAs was seen in PMBSF in P7 mice. This qualitative assessment was confirmed by measuring the area of individual patches sizes and the overall size of PMBSF. No differences were found between WT and RII $\beta$ KO mice in size of the PMBSF or in the size of individual TCA patches (supplemental Fig. 4, available at www.jneurosci. org as supplemental material). In the AS subregion, a different pattern emerged. RII $\beta$ KO animals showed a clear reduction in TCA segregation (Fig. 3A,B; supplemental Fig. 5, available at www.jneurosci.org as supplemental material). Individual TCA patches became difficult to identify. Although TCA segregation was reduced within the AS, the major demarcations between AS and other subregions within SI were not disrupted (Fig. $3 A, B$, arrows), indicating that the loss of RII $\beta$ impairs segregation within AS rather than causing a more general defect in TCA pathfinding. Hence, the barrel phenotype of the $\mathrm{RII} \beta \mathrm{KO}$ mice is similar to those of the phospholipase C- $\beta 1$ (PLC- $\beta 1$ ), mGluR5, 


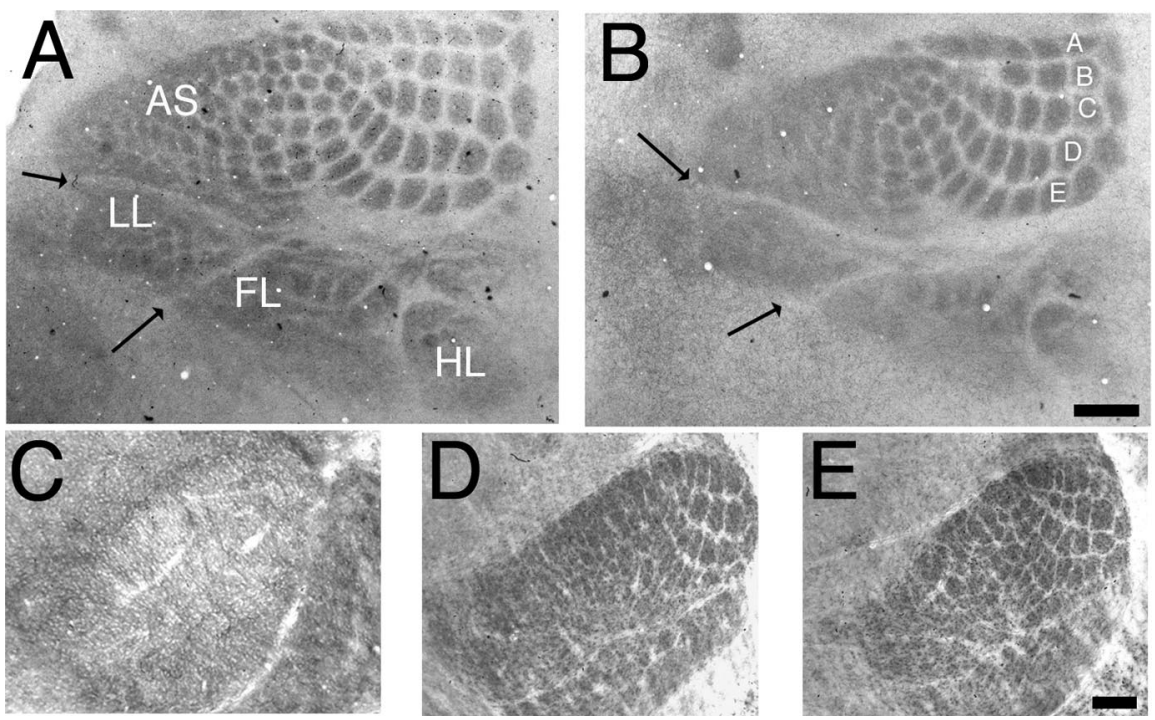

Figure 3. TCAs segregate normally in PMBSF but not in anterior snout regions in R\|l $\beta$ KO mice. $A, B$, SERT immunohistochemical staining of tangential sections through layer IV at P7 reveals clear TCA patches in PMBSF in WT $(\boldsymbol{A})$ and RII $\beta$ KO $(\boldsymbol{B})$ mice. In RII $\beta$ $\mathrm{KO}$ mice, staining appears more uniform in the AS regions with only the largest, more dorsomedial, patches being visible. The demarcations between different subregions (arrows) of SI were clearly visible in both WT and R\|l $\beta \mathrm{KO}$ mice, indicating that the loss of segregation within AS is not a result of a general problem of TCA pathfinding in this region. LL, Lower lip; FL, forelimb; HL, hindlimb. The five main rows barrels representing the five rows of mystacial vibrissas on the facepad are labeled as $A-E$ in $\boldsymbol{B}$. To assess TCA segregation in PMBSF, area measurements of PMBSF and TCA patches of barrels B2, B3, C2, C3, D2, and D3 were performed blind to genotype (supplemental Fig. 4, available at www.jneurosci.org as supplemental material) on five WT and six RII $\beta$ KO P7 mice. No significant differences in any of these measurements were observed (PMBSF, $p=0.66 ; B 2, p=0.30 ; B 3, p=$ $0.43 ; C 2, p=0.36 ; C 3, p=0.39 ; D 2, p=0.55 ; D 3, p=0.47)$. Rll $\beta$ is expressed in developing $S I$ and VpM, but barreloids form normally in R\| $\beta \mathrm{KO}$ mice. RII $\beta$ is expressed at low levels in VpM and barreloids appear normal in R\| $\beta$ KO mice. C, At P7, RII $\beta$ immunostaining can be seen throughout $V p M$ with highest levels in the inter-barreloid regions. $\boldsymbol{D}, \boldsymbol{E}$, Cytochrome oxidase staining of coronal sections through the VpM nucleus of P7 WT (D) and RIl $\beta$ KO $(\boldsymbol{E})$ mice revealed clear barreloids even in the regions representing the anterior snout whiskers. Scale bar: (in $\boldsymbol{B}) \boldsymbol{A}, \boldsymbol{B}, 200 \mu \mathrm{m}$; (in $\boldsymbol{E}) \boldsymbol{C}-\boldsymbol{E}, 80 \mu \mathrm{m}$.

and cortex-specific NR1 (Erzurumlu and Kind, 2001; Kind and Neumann, 2001) knock-out mice in that no cortical barrels are present despite at least partial segregation of TCAs. These findings are consistent with a postsynaptic role for PKA signaling in barrel formation.

Further support for a role for cortically expressed RII $\beta$ in barrel development was provided by analysis of barreloid formation in the thalamic ventral posterior medial $(\mathrm{VpM})$ nucleus that projects to SI. Immunohistochemistry for RII $\beta$ reveals a diffuse staining throughout thalamus at P7. In VpM, the inter-barreloid regions are the most deeply stained with low levels of staining in the center of the barreloids (Fig. 3C). Barreloid segregation within $\mathrm{VpM}$, examined using cytochrome oxidase histochemistry, in $\mathrm{RII} \beta \mathrm{KO}$ mice $(n=7)$ appeared indistinguishable from that in WT mice (Fig. $3 D, E)$.

\section{$\mathrm{RII} \boldsymbol{\beta}$ is expressed in the PSD of layer IV synapses}

$\mathrm{RII} \beta$ associates with mature PSDs via its interaction with A-kinase anchor proteins (AKAPs). To determine whether RII $\beta$ selectively associates with PSD in developing SI, we performed immunoelectron microscopy of layer IV of P14 SI cortex. RII $\beta$ localizes to some, but not all, dendrites and dendritic spines (Fig. 4). The postsynaptic density was particularly strongly stained by the $\mathrm{DAB}$ reaction product. The absence of $\mathrm{RII} \beta$ at some synapses was not a result of poor antibody penetration, because immunopositive dendrites (Fig. 4D,E, asterisks) were visible adjacent to the immunonegative synapses. The RII $\beta$-AKAP-PSD-95 complex has been shown to associate with the PSD in a $\mathrm{Ca}^{2+}$. dependent manner (Colledge et al., 2000; Snyder et al., 2005). To determine whether the association of RII $\beta$ with the PSD is dependent on $\mathrm{Ca}^{2+}$ in developing SI, we isolated PSDs from P7 SI cortex in the presence or absence of $100 \mu \mathrm{m} \mathrm{Ca}^{2+}$ (Fig. $4 F)$. In the presence of $\mathrm{Ca}^{2+}, \mathrm{RII} \beta$ is in the soluble fraction, and in the absence of $\mathrm{Ca}^{2+}$, it associates with the pellet fraction.

\section{Expression of other subunits in RII $\beta$ KO mice}

The expression of PKA subunit genes and the activity of PKA in postnatal SI cortex were examined in P7 WT and RII $\beta \mathrm{KO}$ mice to determine whether there are any compensatory changes in PKA subunit expression in RII $\beta$ KO mice. Western blots of homogenates from WT and RII $\beta$ KO animals (Fig. 5A) did not detect differences in the levels of other PKA regulatory subunits. The level of $\mathrm{C}$ subunits was reduced by $35 \%$ in RII $\beta$ KO mice compared with WT, but this difference was not significant $[720$ optical density units (ODU) $\pm 116, n=4$ vs 1107 ODU \pm 180 , $n=4$; $t$ test, $p=0.12$ ] (supplemental Fig. 4 , available at www.jneurosci.org as supplemental material). Reduced catalytic subunits in adult forebrain of $\operatorname{RII} \beta \mathrm{KO}$ mice has been reported previously (Brandon et al., 1995, 1998). In agreement with the apparent lack of compensation by other subunits in the RII $\beta \mathrm{KO}$ mice and with the suggestion of lower levels of catalytic subunits, we found that total protein kinase A activity was reduced by $40 \%$ in SI of 1 -week-old RII $\beta$ knock-out mice relative to wild-type controls ( $t$ test, $p=0.006$ ) (Fig. $5 B$ ). The higher basal PKA activity in RII $\beta$ KO mice $(p=0.0004)$ may be because of constitutive activity of $\mathrm{C}$ subunits (Niswender et al., 2005).

\section{RII $\beta$, the PSD, and GluRA}

Previous findings from several laboratories have indicated a crucial role for PKA in regulating GluRA insertion into the PSD during plasticity (Malinow and Malenka, 2002). GluRA, an AMPA receptor subunit also known as GluR1, is present throughout SI cortex at both P4 (data not shown) and P7 (Fig. $6 A, B)$. Specificity of the antibody was confirmed by the complete absence of staining in GluRA KO animals (supplemental Fig. 2, available at www.jneurosci.org as supplemental material). Staining was seen throughout the cortex and labels both neuronal soma and neuropil consistent with a synaptic localization. In layer IV (Fig. 6B), clear neuronal and neuropilar staining is visible; however, the neuropilar staining is somewhat reduced compared with other layers. GluRA is also expressed in developing $\mathrm{VpM}$, but levels appear low compared with both cortex and the rest of the thalamus (Fig. $6 \mathrm{C}$ ).

To determine whether loss of RII $\beta$ would disturb the role of PKA in regulating GluRA insertion into the PSD during barrel formation, we examined the level of GluRA in synaptosome preparations from P7 SI cortex (Fig. 6E,F). There was a significant reduction in GluRA expression in $\mathrm{RII} \beta \mathrm{KO}$ mice relative to WT animals but no reduction in the levels of PSD-95 (data not 
shown) or SAP-102 (Fig. 6F; supplemental Fig. 4, available at www.jneurosci.org as supplemental material). To determine whether this disruption of the regulation of GluRA insertion could be responsible for the defects in barrel segregation observed in the RII $\beta$ KO mice, we examined the barrel field of GluRA KO mice $(n=4)$ in Nissl-stained tangential sections through layer IV (Fig. 6D). Barrel segregation appeared normal with good segregation in both PMBSF and anterior snout whisker regions. These data indicate that although RII $\beta$-containing PKA holoenzymes regulate GluRA insertion in developing cortical synapses, this insertion does not appear to play a role in barrel development.

\section{Discussion}

One of the five viable PKA subunitspecific knock-out mouse lines examined here displayed poorly defined barrels. In mice lacking the RII $\beta$ subunit, the contrast in cell density of the barrel hollows relative to the sides was dramatically reduced. Although there were defects in segregation of TCAs in the anterior snout whisker region, segregation of the TCAs in the PMBSF appeared normal. The finding that RII $\beta$ KO mice had the poorest barrel morphology may not be surprising because they have the largest reported decrease in PKA activity and other signs of neurologic disorder (Brandon et al., 1997, 1998). PKA activity is reduced by $40 \%$ in the primary somatosensory cortex of 1 -week-old RII $\beta$ KO mice, with no evidence of compensation in the expression of other PKA regulatory subunits.

The site of gene action in RII $\beta$ KO mice appears to be postsynaptic in barrel cortex because RII $\beta$ was immunolocalized to dendrites and dendritic spines and because the barrelfield phenotype resembles that of PLC- $\beta 1$ and cortex-specific NR1 KO mice (Iwasato et al., 2000; Hannan et al., 2001). The $\mathrm{Ca}^{2+}$-dependent association of RII $\beta$ with the PSD in SI indicates that it is acting downstream of glutamate receptor signaling to regulate barrel development. Finally, mice lacking RII $\beta$ show reduced GluRA insertion into the PSD in P7 SI cortex; however, this reduction is unlikely to regulate barrel formation because GluRA KO mice develop normal barrels. Our results clearly demonstrate a role for postsynaptic PKA signaling pathways in barrel differentiation and are in complete agreement with previous studies showing that glutamate neurotransmission is critical for barrel formation (Fox et al., 1996; Iwasato et al., 2000; Hannan et al., 2001; Barnett et al., 2006).

We also conclude that RII $\beta$-containing PKA holoenzymes are not the downstream targets of $\mathrm{AC} 1$ in the pathway responsible for the barrelless $\left(A d c y 1^{b r l}\right)$ trait, because the phenotype of RII $\beta$ KO mice differs markedly from those of $A d c y 1^{b r l}$ mutant (Welker et al., 1996; Abdel-Majid et al., 1998) and monoamine oxidase A (Cases et al., 1995, 1996) and SERT (Salichon et al., 2001) KO mice.
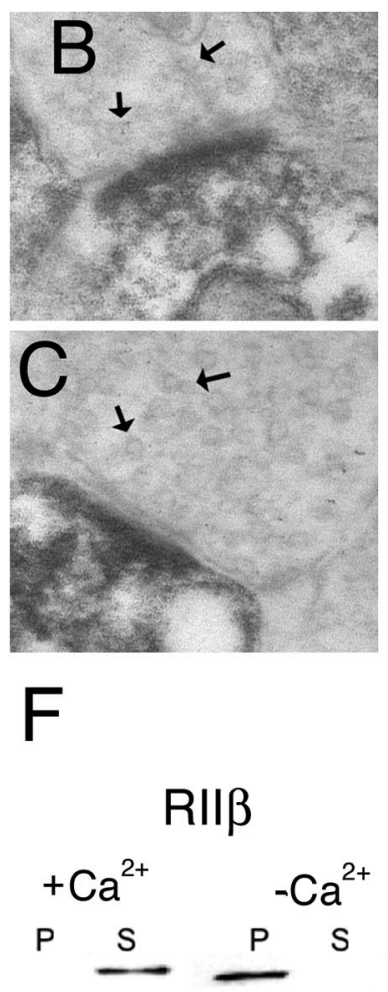
(a)

$P$

Figure 4. $\quad$ RII $\beta$ is postsynaptic in developing SI cortex. $\boldsymbol{A}-\boldsymbol{C}$, Electron micrographs of layer IV of P14 barrel cortex reveal dark Rll $\beta$ immunoreaction product within postsynaptic densities and dendrites $(\boldsymbol{A}-\boldsymbol{C})$, but not of presynaptic terminals. Synapses can be clearly identified by the presence of presynaptic vesicles (arrows) opposite an electron dense PSD. $\boldsymbol{D}, \boldsymbol{E}$, Not all synapses in laye (he presence of DAB reaction product in adjacent dendrites (asterisks) indicates that the absence of
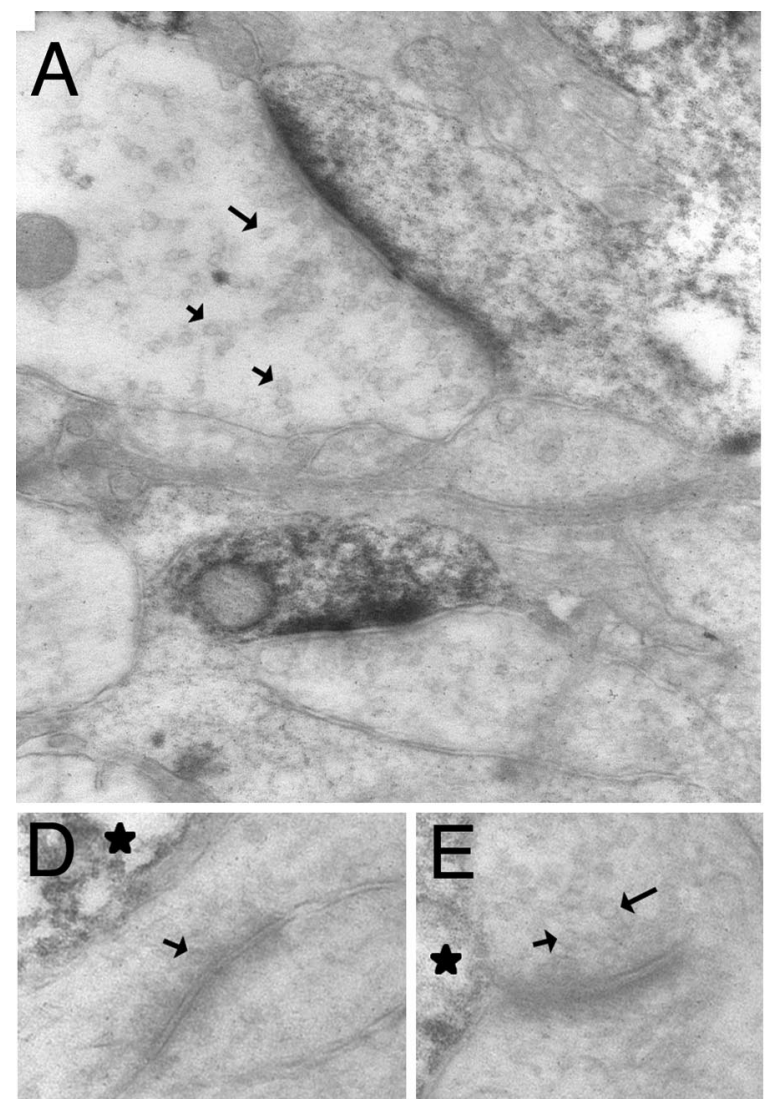

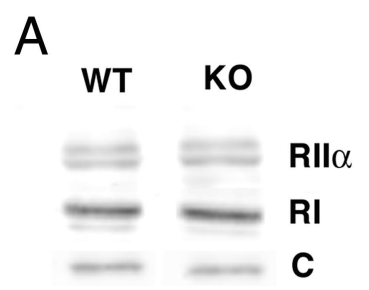

Figure 5. Protein expression of other PKA regulatory subunits in $\mathrm{SI}$ cortex of RII $\beta \mathrm{KO}$ mice. $\boldsymbol{A}$, Western blot analyses of homogenates from SI dissections from P7 mice show no significant difference in the levels of RI, RII $\alpha$, and C subunits between WT and RII $\beta$ KO mice. Measurements of protein density expressed as optical density units confirm these qualitative assessments (supplemental Fig. 4, available at www.jneurosci.org as supplemental material; sample sizes are indicated above each bar). $\boldsymbol{B}$, Consistent with the observed lack of compensation of protein concentration, total protein kinase Aactivity in the SI of P7 RII $\beta$ KO mice $(n=4)$ was lower than in P7 wild-type mice $(n=3)$. Basal and total enzyme activity in protein homogenates was measured in the absence (white bars) and presence (black bars) of $5 \mu \mathrm{m}$ CAMP, respectively. $U$, Picomoles of inorganic orthophosphate transferred per minute. Error bars represent SEM.

\section{The postsynaptic role of RII $\beta$ in barrel formation}

PKA regulatory subunits, through their interaction with AKAP, impart specificity of localization to PKA holoenzymes. RII $\beta$ associates with the NMDA receptor in the postsynaptic density via an AKAP79/150-membrane-associated guanylate kinase scaffolding complex (Colledge et al., 2000; Snyder et al., 2005). Therefore, loss of RII $\beta$ may lead to ectopic or constitutive PKA 


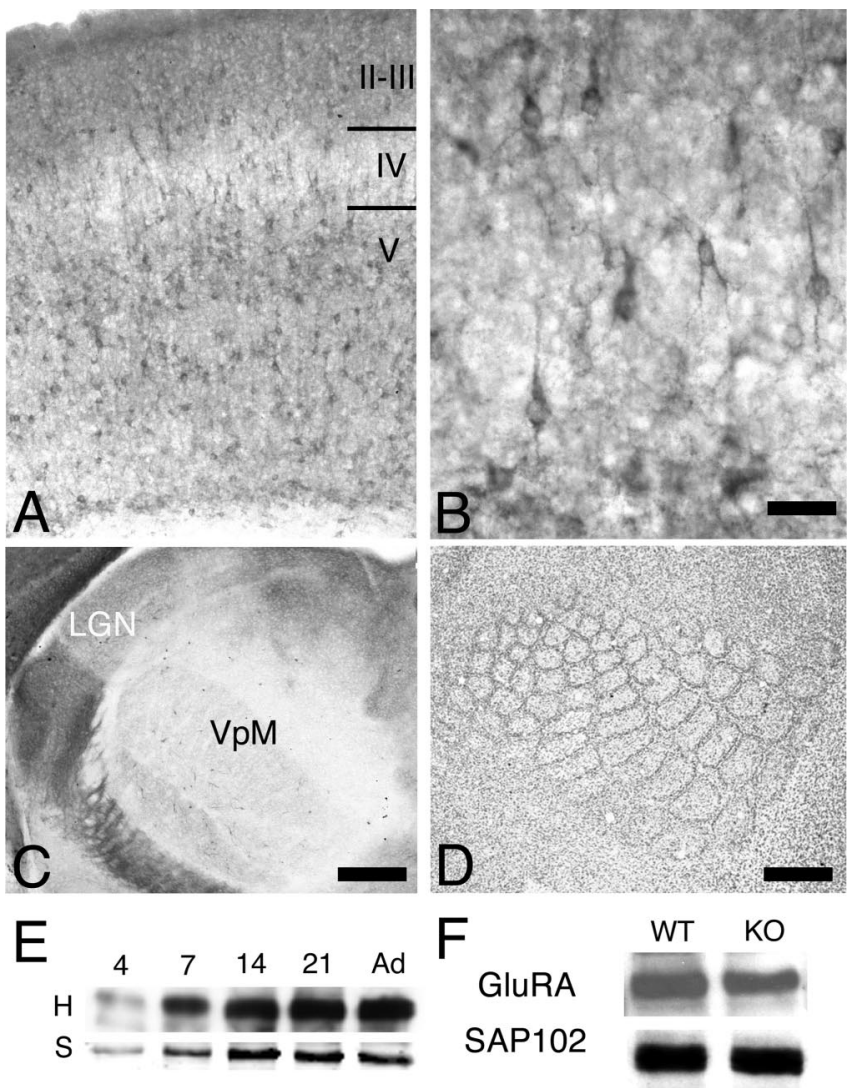

Figure 6. RIII $\beta$ regulates GluRA insertion independent of barrel formation. $A$, GluRA immunolocalization in $\mathrm{SI}$ of $\mathrm{P7}$ animals reveals staining throughout the cortex with highest levels in layers II/II and V. B, Higher-magnification images through layer IV show clear immunopositive neurons and diffuse neuropilar staining. $C$, Staining is also visible in P7 thalamus with lowest levels in VpM. $\boldsymbol{E}$, Western blot analysis demonstrated a rapid increase in the levels of GluRA in homogenates $(H)$ and synaptosome $(S)$ preparations during the first postnatal week, consistent with the rapid increase in synapses during this period. Ad, Adult. $\boldsymbol{F}$, To determine whether RII $\beta$ is necessary for insertion of GluRA into the PSD, Western blot analyses of synaptosome preparations from SI of 7-d-old WT and Rll $\beta$ KO mice were performed. In each experiment, GluRA levels in RII $\beta \mathrm{KO}$ mice are normalized to WT levels. RII $\beta \mathrm{KO}$ mice have significantly less GluRA $(74.4 \% \pm 6.8 ; n=5 ; 1$-sample $t$ test, $p=0.006)$ (supplemental Fig. 4 , available at www.jneurosci.org as supplemental material) in synaptosomes than WT mice $(n=5 ; 100 \%)$. No differences in SAP-102 (F) or PSD-95 levels (data not shown) or in GluRA levels in homogenates (data not shown) were seen, indicating that the decrease in GluRA was not simply caused by a general decrease in PSD components in RII $\beta$ KO mice. Nissl staining through layer IV of adult GluRA KO mice $(\boldsymbol{D})$ reveals clear cellular segregation throughout the barrelfield, including in the anterior snout representations, indicating that neither GluRA insertion nor its presence are necessary for barrel formation. Scale bar: (in $\boldsymbol{B}) \boldsymbol{A}, 140 \mu \mathrm{m} ; \boldsymbol{B}, 35 \mu \mathrm{m} ; \boldsymbol{C}, 250 \mu \mathrm{m} ; \boldsymbol{D}, 350 \mu \mathrm{m}$.

activity. In P7 mice, we found that loss of RII $\beta$ results in a slight increase in basal PKA activity and a dramatic reduction in stimulated levels of PKA activity, indicating that there is an increase in free catalytic subunits in RII $\beta$ KO mice but that total catalytic subunit concentrations may be lower. Although this expected reduction in catalytic subunit expression was not statistically significant in our P7 barrel cortex homogenates, Inan et al. (2006) found a reduction in P11 barrel cortex homogenates. Nonetheless, the key questions in defining the role of RII $\beta$-containing PKA holoenzymes in postsynaptic signaling pathways involved in barrel formation include the identity of the PKA activator(s), the relevant PKA phosphorylation substrate(s), and the mecha$\operatorname{nism}(\mathrm{s})$ by which they influence barrel formation.

Our results showing a reduction in PSD-associated GluRA in the $\operatorname{RII} \beta$ KO mice identify $\operatorname{RII} \beta$ as the regulatory subunit that is responsible for regulating AMPA receptor insertion and synaptic plasticity in developing thalamocortical synapses ( $\mathrm{Lu}$ et al., 2003). Our results are in agreement with those showing a role for PKA in ocular dominance plasticity (Beaver et al., 2001) and those showing phosphorylation of GluRA at a PKA-dependent site (Ser845) regulates GluRA insertion into the PSD in visual cortex (Heynen et al., 2003). More recently, RII $\beta$ has been shown to regulate LTP at developing layer IV synapses in SI (Inan et al., 2006). PKA also phosphorylates GluRD receptors to regulate their insertion into the PSD (Carvalho et al., 1999; Esteban et al., 2003). We have been unable to detect significant GluRD levels in SI during barrel development (data not shown), in agreement with previous findings (Catania et al., 1995). We know of no evidence for phosphorylation of GluRB or GluRC by PKA.

The finding that GluRA KO mice develop normal barrels strongly suggests that although RII $\beta$ does regulate GluRA insertion and barrel formation, these two events are not causally related. Our findings are also in good agreement with previous findings that dissociate barrel development from mechanisms that underlie synaptic plasticity. For example, after row $\mathrm{C}$ follicle ablation, the cells still cluster around the fused row of TCAs to form a "megabarrel" (Van der Loos and Woolsey, 1973). The clustering of layer IV cells despite the absence of the corresponding follicles strongly indicates that patterned release of glutamate, in a manner similar to that needed to induce synaptic plasticity, is unlikely to regulate barrel development. Similarly, in mice in which barrel formation is delayed by early overexpression of 5-HT, barrel formation takes place even in the absence of whisker follicles (Rebsam et al., 2005).

\section{Activation of postsynaptic PKA in barrel formation}

Both NMDA and mGluR5 glutamate receptors can activate PKA (Kind and Neumann, 2001). Our finding that association of RII $\beta$ with the PSD is $\mathrm{Ca}^{2+}$ dependent is in good agreement with this hypothesis and previous findings showing a similar NMDA receptor-dependent association with the PSD in hippocampal neurons (Snyder et al., 2005). RII $\beta$-containing holoenzymes could be regulated by NMDA receptors through $\mathrm{Ca}^{2+} / \mathrm{CaM}-$ dependent adenylyl cyclases. AC1 and AC8 are both expressed in layer IV neurons during barrel development (Nicol et al., 2005); however, neither AC8 KO mice (Abdel-Majid et al., 1998) nor cortex-specific AC1 KO mice (Iwasato et al., 2005) have obvious defects in barrel development. Perhaps these adenylyl cyclases can compensate for each other to regulate cellular segregation in layer IV.

The $\mathrm{Ca}^{2+}$ signal need not come from the NMDA receptor. mGluR5 can also increase release of $\mathrm{Ca}^{2+}$ from intracellular stores via the activation of PLC- $\beta 1$ and subsequent generation of $\mathrm{IP}_{3}$ (Hannan et al., 2001). In fact, the similarity of the phenotypes of PLC- $\beta 1$ and RII $\beta$ KO mice suggests that RII $\beta$ activation may be downstream of mGluR5 activation of PLC- $\beta 1$ in mediating barrel development.

Alternatively, PKA may be activated by other ACs or by a cAMP-independent mechanism. Regulation of $\mathrm{Ca}^{2+} / \mathrm{CaM}-$ independent adenylyl cyclases by mGluR5 may be the key pathway in RII $\beta$-mediated barrel development. Both AC4 (Defer et al., 2000) and AC9 (Antoni et al., 1998) are expressed in cortical neurons, and their activities are regulated by $\mathrm{G}_{\mathrm{q}}$, the principal G-protein associated with mGluR5. In addition, a cAMPindependent form of type II PKA activation has been identified recently ( $\mathrm{Ma}$ et al., 2005), raising the possibility that RII $\beta$ containing holoenzymes may be regulating barrel development independent of adenylyl cyclases. 


\section{cAMP signaling in the presynaptic terminal in barrel formation}

The barrelless phenotype in Adcyl mutant mice revealed the involvement of cAMP intracellular signaling pathways in patterning of the mouse SI cortex (Welker et al., 1996; Abdel-Majid et al., 1998). The hypothesis that the site of gene action of $A d c y 1^{b r l}$ is presynaptic was confirmed recently in somatosensory cortex using cortex-specific AC1 KO mice (Iwasato et al., 2005). It appears to have a similar presynaptic role in retinal ganglion cell projections (Nicol et al., 2006). Low AC1 activity in TCA presynaptic terminals, either because of a loss-of-function Adcyl mutation or increased stimulation of $5-\mathrm{HT}_{1 \mathrm{~B}}$ serotonin receptors, causes a barrelless phenotype, perhaps by suppressing glutamate transmission (Abdel-Majid et al., 1998; Salichon et al., 2001; Gaspar et al., 2003). We found no evidence that PKA is the principal target of $\mathrm{AC} 1$ in presynaptic signaling pathways involved in barrel formation, but the lack of a phenotype in most of the PKA mutant mice examined may reflect compensation between subunits in individual subunit KOs, as has been found in other tissue (Brandon et al., 1995, 1997, 1998; Amieux et al., 2002). Or RI $\alpha$ may be a key regulatory subunit; however, the embryonic lethality of these KO mice (Amieux et al., 2002) prevented their analysis.

Alternatively, PKA may not be the principal downstream target of cAMP generated by AC1. Other possible targets of cAMP signaling are cAMP-regulated guanine nucleotide exchange factors (Kawasaki et al., 1998) and cyclic-nucleotide-gated (CNG) channels (Kaupp, 1995; Zimmerman, 1995). In Caenorhabditis elegans, sensory axons of CNG channel (tax-2 and tax-4 mutants) terminate in inappropriate regions, bypassing their normal site of termination (Coburn et al., 1998). The fact that barrelless mice display excessive lateral growth of TCAs in layer IV (Welker et al., 1996) is consistent with the hypothesis that low levels of cAMP in TCAs would be associated with low CNG channel activity.

We and others have shown previously that the process of TCA segregation can be genetically dissociated from the process of cellular segregation in layer IV. Whereas the former is dependent on $5-\mathrm{HT}_{1 \mathrm{~B}}$ receptor signaling, likely via $\mathrm{AC} 1$, the latter is dependent on glutamate receptor signaling via $\mathrm{RII} \beta$-containing PKA holoenzymes, PLC- $\beta 1$, and SynGAP. Furthermore, although RII $\beta$ regulates GluRA insertion and synaptic plasticity, its regulation of cellular segregation is independent of these changes in synaptic strength.

\section{References}

Abdel-Majid RM, Leong WL, Schalkwyk LC, Smallman DS, Wong ST, Storm DR, Fine A, Dobson MJ, Guernsey DL, Neumann PE (1998) Loss of adenylyl cyclase I activity disrupts patterning of mouse somatosensory cortex. Nat Genet 19:289-291.

Amieux PS, Howe DG, Knickerbocker H, Lee DC, Su T, Laszlo GS, Idzerda RL, McKnight GS (2002) Increased basal cAMP-dependent protein kinase activity inhibits the formation of mesoderm-derived structures in the developing mouse embryo. J Biol Chem 277:27294-27304.

Antoni FA, Palkovits M, Simpson J, Smith SM, Leitch AL, Rosie R, Fink G, Paterson JM (1998) $\mathrm{Ca}^{2+} /$ calcineurin-inhibited adenylyl cyclase, highly abundant in forebrain regions, is important for learning and memory. J Neurosci 18:9650-9661.

Barnett MW, Old RW, Jones EA (1998) Neural induction and patterning by fibroblast growth factor, notochord and somite tissue in Xenopus. Dev Growth Differ 40:47-57.

Barnett MW, Watson RF, Vitalis T, Porter K, Komiyama NH, Stoney PN, Gillingwater TH, Grant SGN, Kind PC (2006) SynGAP regulates pattern formation in the trigeminal system of mice. J Neurosci 26:1355-1365.

Beaver CJ, Ji Q, Fischer QS, Daw NW (2001) Cyclic AMP-dependent protein kinase mediates ocular dominance shifts in cat visual cortex. Nat Neurosci 4:159-163.

Brandon EP, Gerhold KA, Qi M, McKnight GS, Idzerda RL (1995) Deriva- tion of novel embryonic stem cell lines and targeting of cyclic AMPdependent protein kinase genes. Recent Prog Horm Res 50:403-408.

Brandon EP, Idzerda RL, McKnight GS (1997) PKA isoforms, neural pathways, and behaviour: making the connection. Curr Opin Neurobiol 7:397-403.

Brandon EP, Logue SF, Adams MR, Qi M, Sullivan SP, Matsumoto AM, Dorsa DM, Wehner JM, McKnight GS, Idzerda RL (1998) Defective motor behavior and neural gene expression in RII $\beta$-protein kinase A mutant mice. J Neurosci 18:3639-3649.

Carvalho AL, Kameyama K, Huganir RL (1999) Characterization of phosphorylation sites on the glutamate receptor 4 subunit of the AMPA receptors. J Neurosci 19:4748-4754.

Cases O, Seif I, Grimsby J, Gaspar P, Chen K, Pournin S, Muller U, Aguet M, Babinet C, Shih JC, De Maeyer E (1995) Aggressive behavior and altered amounts of brain serotonin and norepinephrine in mice lacking MAOA. Science 268:1763-1766.

Cases O, Vitalis T, Seif I, De Maeyer E, Sotelo C, Gaspar P (1996) Lack of barrels in the somatosensory cortex of monoamine oxidase A-deficient mice: role of a serotonin excess during the critical period. Neuron 16:297-307.

Catania MV, Tolle TR, Monyer H (1995) Differential expression of AMPA receptor subunits in NOS-positive neurons of cortex, striatum, and hippocampus. J Neurosci 15:7046-7061.

Clegg CH, Correll LA, Cadd GG, McKnight GS (1987) Inhibition of intracellular cAMP-dependent protein kinase using mutant genes of the regulatory type I subunit. J Biol Chem 262:13111-13119.

Coburn CM, Mori I, Ohshima Y, Bargmann CI (1998) A cyclic nucleotidegated channel inhibits sensory axon outgrowth in larval and adult Caenorhabditis elegans: a distinct pathway for maintenance of sensory axon structure. Development 125:249-258.

Colledge M, Dean RA, Scott GK, Langeberg LK, Huganir RL, Scott JD (2000) Targeting of PKA to glutamate receptors through a MAGUK-AKAP complex. Neuron 27:107-119.

Defer N, Best-Belpomme M, Hanoune J (2000) Tissue specificity and physiological relevance of various isoforms of adenylyl cyclase. Am J Physiol Renal Physiol 279:F400-F416.

Dunkley PR, Jarvie PE, Heath JW, Kidd GJ, Rostas JA (1986) A rapid method for isolation of synaptosomes on Percoll gradients. Brain Res 372:115-129.

Erzurumlu RS, Kind PC (2001) Neural activity: sculptor of "barrels" in the neocortex. Trends Neurosci 24:589-595.

Esteban JA, Shi SH, Wilson C, Nuriya M, Huganir RL, Malinow R (2003) PKA phosphorylation of AMPA receptor subunits controls synaptic trafficking underlying plasticity. Nat Neurosci 6:136-143.

Fischer QS, Beaver CJ, Yang Y, Rao Y, Jakobsdottir KB, Storm DR, McKnight GS, Daw NW (2004) Requirement for the RII $\beta$ isoform of PKA, but not calcium-stimulated adenylyl cyclase, in visual cortical plasticity. J Neurosci 24:9049-9058.

Fox K, Schlaggar BL, Glazewski S, O’Leary DD (1996) Glutamate receptor blockade at cortical synapses disrupts development of thalamocortical and columnar organization in somatosensory cortex. Proc Natl Acad Sci USA 93:5584-5589.

Gaspar P, Cases O, Maroteaux L (2003) The developmental role of serotonin: news from mouse molecular genetics. Nat Rev Neurosci 4:1002-1012.

Hannan AJ, Blakemore C, Katsnelson A, Vitalis T, Huber KM, Bear M, Roder J, Kim D, Shin HS, Kind PC (2001) PLC-beta1, activated via mGluRs, mediates activity-dependent differentiation in cerebral cortex. Nat Neurosci 4:282-288.

Heynen AJ, Yoon BJ, Liu CH, Chung HJ, Huganir RL, Bear MF (2003) Molecular mechanism for loss of visual cortical responsiveness following brief monocular deprivation. Nat Neurosci 6:854-862.

Inan M, Lu HC, Albright MJ, She WC, Crair MC (2006) Barrel map development relies on PKARII $\beta$-mediated cAMP signaling. J Neurosci, 26:4338-4349.

Iwasato T, Datwani A, Wolf AM, Nishiyama H, Taguchi Y, Tonegawa S, Knopfel T, Erzurumlu RS, Itohara S (2000) Cortex-restricted disruption of NMDAR1 impairs neuronal patterns in the barrel cortex. Nature 406:726-731.

Iwasato T, Lee LJ, Ando R, Saito YM, Kanki H, Muglia LJ, Erzurumlu RS, Itohara S (2005) Calcium-stimulated adenylyl cyclase in cortical excita- 
tory neurons is not essential for barrel formation in the mouse somatosensory cortex. Soc Neurosci Abstr 31:716.5.

Kaupp UB (1995) Family of cyclic nucleotide gated ion channels. Curr Opin Neurobiol 5:434-442.

Kawasaki H, Springett GM, Mochizuki N, Toki S, Nakaya M, Matsuda M, Housman DE, Graybiel AM (1998) A family of cAMP-binding proteins that directly activate Rap1. Science 282:2275-2279.

Kind P, Blakemore C, Fryer H, Hockfield S (1994) Identification of proteins down-regulated during the postnatal development of the cat visual cortex. Cereb Cortex 4:361-375.

Kind PC, Neumann PE (2001) Plasticity: downstream of glutamate. Trends Neurosci 24:553-555.

Laurent A, Goaillard JM, Cases O, Lebrand C, Gaspar P, Ropert N (2002) Activity-dependent presynaptic effect of serotonin $1 \mathrm{~B}$ receptors on the somatosensory thalamocortical transmission in neonatal mice. J Neurosci 22:886-900.

Lu HC, She WC, Plas DT, Neumann PE, Janz R, Crair MC (2003) Adenylyl cyclase I regulates AMPA receptor trafficking during mouse cortical 'barrel' map development. Nat Neurosci 6:939-947.

Ma Y, Pitson S, Hercus T, Murphy J, Lopez A, Woodcock J (2005) Sphingosine activates protein kinase A type II by a novel cAMP-independent mechanism. J Biol Chem 280:26011-26017.

Malinow R, Malenka RC (2002) AMPA receptor trafficking and synaptic plasticity. Annu Rev Neurosci 25:103-126.

Nicol X, Muzerelle A, Bachy I, Ravary A, Gaspar P (2005) Spatiotemporal localization of the calcium-stimulated adenylate cyclases, AC1 and AC8, during mouse brain development. J Comp Neurol 486:281-294.

Nicol X, Muzerelle A, Rio JP, Metin C, Gaspar P (2006) Requirement of adenylate cyclase 1 for the ephrin-A5-dependent retraction of exuberant retinal axons. J Neurosci 26:862-872.

Niswender CM, Willis BS, Wallen A, Sweet IR, Jetton TL, Thompson BR, Wu C, Lange AJ, McKnight GS (2005) Cre recombinase-dependent expression of a constitutively active mutant allele of the catalytic subunit of protein kinase A. Genesis 43:109-119.

Qi M, Zhuo M, Skalhegg BS, Brandon EP, Kandel ER, McKnight GS, Idzerda RL (1996) Impaired hippocampal plasticity in mice lacking the Cbetal catalytic subunit of cAMP-dependent protein kinase. Proc Natl Acad Sci USA 93:1571-1576.

Rebsam A, Seif I, Gaspar P (2005) Dissociating barrel development and lesion-induced plasticity in the mouse somatosensory cortex. J Neurosci 25:706-710.

Salichon N, Gaspar P, Upton AL, Picaud S, Hanoun N, Hamon M, De Maeyer E, Murphy DL, Mossner R, Lesch KP, Hen R, Seif I (2001) Excessive activation of serotonin (5-HT) 1B receptors disrupts the formation of sensory maps in monoamine oxidase a and 5-HT transporter knock-out mice. J Neurosci 21:884-896.

Skalhegg BS, Huang Y, Su T, Idzerda RL, McKnight GS, Burton KA (2002) Mutation of the Calpha subunit of PKA leads to growth retardation and sperm dysfunction. Mol Endocrinol 16:630-639.

Snyder EM, Colledge M, Crozier RA, Chen WS, Scott JD, Bear MF (2005) Role for A kinase-anchoring proteins (AKAPS) in glutamate receptor trafficking and long term synaptic depression. J Biol Chem 280:16962-16968.

Spires TL, Molnar Z, Kind PC, Cordery PM, Upton AL, Blakemore C, Hannan AJ (2005) Activity-dependent regulation of synapse and dendritic spine morphology in developing barrel cortex requires phospholipase C-beta1 signalling. Cereb Cortex 15:385-393.

Van der Loos H, Woolsey TA (1973) Somatosensory cortex: structural alterations following early injury to sense organs. Science 179:395-398.

Vitalis T, Cases O, Gillies K, Hanoun N, Hamon M, Seif I, Gaspar P, Kind P, Price DJ (2002) Interactions between TrkB signaling and serotonin excess in the developing murine somatosensory cortex: a role in tangential and radial organization of thalamocortical axons. J Neurosci 22:4987-5000.

Welker E, Armstrong-James M, Bronchti G, Ourednik W, GheorghitaBaechler F, Dubois R, Guernsey DL, Van der Loos H, Neumann PE (1996) Altered sensory processing in the somatosensory cortex of the mouse mutant barrelless. Science 271:1864-1867.

White EL, Weinfeld L, Lev DL (1997) A survey of morphogenesis during the early postnatal period in PMBSF barrels of mouse SmI cortex with emphasis on barrel D4. Somatosens Mot Res 14:34-55.

Wong-Riley M (1979) Changes in the visual system of monocularly sutured or enucleated cats demonstrable with cytochrome oxidase histochemistry. Brain Res 171:11-28.

Woolsey TA, Van der Loos H (1970) The structural organization of layer IV in the somatosensory region (SI) of mouse cerebral cortex. The description of a cortical field composed of discrete cytoarchitectonic units. Brain Res 17:205-242.

Zamanillo D, Sprengel R, Hvalby O, Jensen V, Burnashev N, Rozov A, Kaiser KM, Koster HJ, Borchardt T, Worley P, Lubke J, Frotscher M, Kelly PH, Sommer B, Andersen P, Seeburg PH, Sakmann B (1999) Importance of AMPA receptors for hippocampal synaptic plasticity but not for spatial learning. Science 284:1805-1811.

Zimmerman AL (1995) Cyclic nucleotide gated channels. Curr Opin Neurobiol 5:296-303. 